\title{
Saprotrophic capabilities as functional traits to study functional diversity and resilience of ectomycorrhizal community
}

\author{
Ken Cullings $\cdot$ Pierre-Emmanuel Courty
}

Received: 22 June 2009 / Accepted: 28 July 2009 / Published online: 15 August 2009

(C) Springer-Verlag 2009

\begin{abstract}
In an accompanying editorial Dr Petr Baldrian made a case casting doubt on our recent work addressing the saprophytic potential of ectomycorrhizal (EM) fungi. Dr Baldrian's statements illustrate a very valid truth: the book is still very much open on this subject. The point he raised that the only logical reason for these fungi to be responding to high carbon demand or decreased host photosynthetic capacity by up-regulating enzymes is for the purpose of carbon acquisition is valid as well. Despite this, he makes the case that there is no compelling evidence that EM fungi exhibit saprophytic activity. The concept central to Dr Baldrian's conclusion is that even though some EM fungi possess the genes necessary for saprophytic behaviour and may even express these genes, EM fungi do not inhabit a position in the soil column that provides access to usable substrate. In this paper we present both previously published and newly obtained data that demonstrate that this assumption is erroneous, and we present arguments that place the saprophytic potential of EM fungi within a broad ecological context.
\end{abstract}

Keywords Ectomycorrhizae $\cdot$ Saprophytic ·

Ecosystem function $\cdot$ Enzymes

Communicated by Russell Monson.

K. Cullings $(\bowtie)$

NASA-Ames Research Center, MS 239-11,

Moffett Field, CA 94035-1000, USA

e-mail: cullings1@earthlink.net; kcullings@mail.arc.nasa.gov

P.-E. Courty

Botanical Institute, University of Basel, 4056 Basel, Switzerland

e-mail: pierre.courty@unibas.ch

\section{Introduction}

While it is true that studies indicate that some ectomycorrhizal (EM) fungi are restricted to mineral soil, it is equally clear that many EM fungi do in fact inhabit organic-rich soil layers (e.g. Goodman and Trofymow 1998; Rosling et al. 2003; Tedersoo et al. 2003; Baier et al. 2006). Furthermore, EM abundance can in fact be highest in these layers (e.g. Neville et al. 2002; Baier et al. 2006). In a recent study, we showed that the EM root tips are more abundant in the superficial horizon than in deeper soil horizons (Courty et al. 2008a; Fig. 1) and that some EM fungi (i.e. Laccaria amethystina, Piloderma croceum, Tomentella fuscocinerea) are associated only with superficial roots. In addition, Piloderma, Tomentella, and Tylospora species may be specifically adapted to organic-rich layers, and even to litter and woody debris (e.g. Dickie et al. 2002; Tedersoo et al. 2003; Buée et al. 2007), and experiments indicate that they may even be able to grow saprophytically on these substrates (e.g. Tedersoo et al. 2003).

Further, even if EM root tips might be restricted to the deeper, mineral layers, the hyphae may grow into the litter providing access to the substrates harboured here. Since our original publications on this topic, we have used molecular methods [PCR amplification of fungal internal transcribed spacer DNA and subsequent cloning, sequencing and BLAST analysis of the PCR products using established methods (e.g. Luis et al. 2004)] to determine whether or not this is the case in the Yellowstone soils utilized in many of our past studies. Results (unpublished, sequences available upon request) indicate that virtually all of the fungal hyphae inhabiting the top, litter/organic layer in these soils belong to EM fungi. These include six species of Cortinarius, two species of Piloderma, Russula turci and Russula nigricans, Tricholoma saponaceum, and 


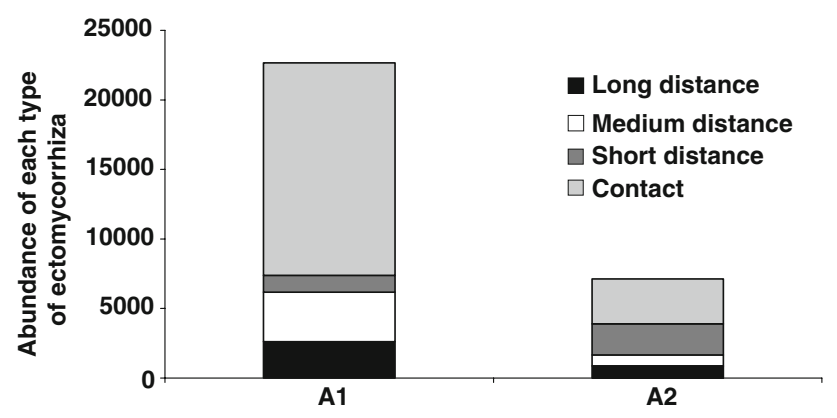

Fig. 1 Abundance of the different exploration types (Agerer 2001) in the A1 $(0-5 \mathrm{~cm})$ and A2 $(5-15 \mathrm{~cm})$ horizon of an oak forest. The abundance of each ectomycorrhizal species was recorded each month over a period of 15 months (Courty et al. 2008a)

Suillus tomentosus. In addition, we detected a species of Ceratobsidium, and Sistotrema alboluteum, and though Ceratomasidium may also be a pathogen, both have more recently been identified as mycorrhizal (e.g. Bidartondo et al. 2004; Nilsson et al. 2006; DiMarino et al. 2008). Hence, in our field sites, EM fungi do in fact occupy and indeed dominate a position in the soil column that allows them direct access to substrate, and as our most recent work clearly demonstrates, they possess the wherewithal to exploit this rich carbon source.

We have also performed controlled experiments in natural settings in order to determine how EM fungi respond to added litter, both in terms of growth and proliferation, and expression of enzymes that could break down this litter. In one, sterilized litter was added to soils devoid of litter (Cullings et al. 2003); results demonstrated strong growth responses by the dominant EM species into the top soil layer, directly adjacent to the added litter. From this, we hypothesized that the fungi exhibiting this response could be utilizing the added litter as a nutrient source. As an initial test of this hypothesis, we performed assays of cellulase, phosphatase and laccase activities in EM roots growing into the litter and found significant increases in all enzymes assayed (Table 1).
Finally, we have found that the growth (mg dry weight) and the growth rate of the mycelium of EM fungus Lactarius quietus are significantly increased in response to the addition of leaf debris (for brevity, data not shown but available upon request). Moreover, we have measured the transcription levels of four targeted L. quietus genes (i.e. a laccase and an exo-chitinase), by quantitative RT-PCR in EMs and in the ectomycorrhizosphere soil (the soil surrounding the EMs containing the extraradical mycelium). The expression of many genes increases in EMs and in the ectomycorrhizosphere relative to pure culture of $L$. quietus and this is presumably because EMs in forest soils are starved of nutrients, particularly nitrogen (Courty et al. 2008b).

Together, our results indicate that not only can EM fungi respond to chemical cues from sterile litter and woody debris with a positive growth response, but that they also express the genes and produce the enzymes necessary to utilize this litter as a nutrient source.

\section{Ecological relevance of secreted enzymes for EM fungi}

As Dr Baldrian maintains, it may also be true that EM fungi typically exhibit enzyme activity at levels lower than those measured in their saprophytic relatives. Strictly speaking, enzyme activity measured in EM root tips does not demonstrate the ability to degrade phenolic compounds, such as cellulose and hemicellulose (Lindahl and Boberg 2008); none of the enzymes assayed in these studies (e.g. Courty et al. 2005, 2006) impart the ability to degrade complex ligno-cellulosic compounds. For example, Tricholoma matsutake is able to secrete $\beta$-glucosidase, which hydrolyses oligosaccharides having a $\beta$-1,4-linkage such as cellobiose, but is not able to hydrolyse polysaccharides such as Avicel and carboxymethyl-cellulose (Kusuda et al. 2006).

Nonetheless, we hold that enzymes expressed by EM fungi are of ecological significance. By degrading organic compounds, including those from their own mycelia and those of other fungi, and channelling nutrients directly to

Table 1 Measures of ergosterol concentrations and enzyme activities following litter addition (means and SEs)

\begin{tabular}{|c|c|c|c|c|c|c|}
\hline \multirow[t]{2}{*}{ Assay } & \multicolumn{3}{|c|}{ Non-mycorrhizal roots } & \multicolumn{3}{|c|}{ EM root tips } \\
\hline & Treatment & Control & $P$-value & Treatment & Control & $P$-value \\
\hline Phosphatase $^{\mathrm{a}}$ & $1.30(0.1)$ & $1.44(0.2)$ & NS & $517(24)$ & $350(29)$ & 0.0002 \\
\hline D-glucosidase ${ }^{b}$ & NA & NA & & $7.9(0.4)$ & $5.7(0.4)$ & 0.008 \\
\hline Laccase $^{c}$ & NA & NA & & $28,900(5)$ & $9,500(5)$ & 0.04 \\
\hline
\end{tabular}

EM Ectomycorrhizal, $N S$ not significant, $N A$ no activity (in either controls or treatments)

${ }^{\text {a }}$ Activity expressed as $\mu \mathrm{M}$ nitrophenol/mg ergosterol

b Activity expressed as $\mu \mathrm{g}$ glucose/mg ergosterol

c Activity expressed as units/mg ergosterol 
the host tree, EM fungi have the capacity to shorten mineralization pathways in which free-living decomposers are involved. In addition, the laccases of several EM fungi can reduce concentrations of small phenolic compounds at rates at least equal to their wood-rotting relatives (e.g. Gramss et al. 1999). Thus, even if EM fungi cannot be linked directly to breakdown of coarse woody tissues, their role in cycling of downstream primary breakdown products, and hence overall carbon cycling, could very well be significant.

Further, one must ask the question "how much activity is significant"? We believe that the answer to this question is largely a matter of scale. From the viewpoint of the fungus, if a fraction of the host carbon is lost, then only a fraction of the activity may be required to fill the gap (i.e. during the bud break period; Courty et al. 2007). This may then suggest to some that the ecological significance of this action is quite small. However, even if only a small fraction (for argument, say 1\%) of the carbon cycling activity in a forest soil can be attributed to EM fungi, this could translate into utilization of millions of tons of sequestered carbon (and a corresponding release of carbon dioxide via respiration) when multiplied over the millions of square miles covered by EM forests in the northern hemisphere alone. Hence, the ecological impact could be far-reaching, and is certainly worthy of consideration, particularly in the light of global climate change scenarios in which the spread of foliar pathogens that limit host carbon availability is thought to be a significant primary impact of the process (e.g. Boland et al. 2004).

A second major point raised by Dr Baldrian is that EM fungi either lack the genes necessary for substrate breakdown, or if they do have them, they possess fewer copies. This is, for the most part, true. However, several studies indicate the potential for significant lignin- and cellulosedegrading enzyme activity both in basidiomycetes (e.g. Luis et al. 2004, 2005; Courty et al. 2009) and ascomycetes (e.g. Kellner et al. 2007). This includes our work which demonstrated that lignin peroxidase activity increased significantly in response to decreased host photosynthetic potential. These data are undiminished by the supposed methodological problems raised by Dr Baldrian; while veratryl alcohol is commonly used, it is untrue that 2,2azino-bis(3- ethylbenzthiazoline-6-sulphonic acid is not a suitable substrate (e.g. Hiner et al. 2002; Gerini et al. 2003). Similarly, while it may be theoretically true that the assay for endocellulase reflects cumulative cellulase activities, this is clearly not the case here. If it were, activities would be higher than those measured for D-glucosidase, when in fact they are 2 orders of magnitude lower. This is also true for manganese peroxidase relative to lignin peroxidase activities. Further, our conclusions are based on relative increases in organic substrate utilization potential in response to treatments that reduce host photosynthetic capacity. These conclusions are not diminished if measures represent increases in broadly defined "peroxidases", a class of enzymes that work in cooperation with laccase in the complex process of wood delignification (reviewed by Leonowicz et al. 2001). Rather, as Dr Baldrian rightly acknowledges, they indicate significant increases in the potential for EM fungi to exploit cellulose, protein and phenolic substrates in response to treatments in field settings.

Hence, even if most EM fungi do possess fewer gene copies, it is not a foregone conclusion that no saprophytic potential exists. In fact, this potential clearly does exist, given the numerous reversals to a saprophytic habit that have occurred through evolution (e.g. Hibbett et al. 2000). As first written by Koide et al. (2008), we suggest that rather than being strict mutualists, EM fungi occupy a position along the biotrophy-saprotrophy continuum. This could be significant ecologically even if, as Dr Baldrian asserts, the apparent saprophytic activity we measured in our experiments represented degradation of dead and dying host material. This is not the case in our experiments; as we thoroughly describe in our methods section (e.g. Cullings et al. 2008) we used only healthy, living EM root tips. However, this could very well be the case in nature. If one were to detect bacteria expressing wood-degrading enzymes in the presence of these dying roots, one would have no qualms with regard to identifying these organisms as decomposers. In the case of EM fungi, the dominant paradigm prevents this conclusion. Yet, as Dr Baldrian rightly states, EM fungi are likely to break down these host tissues, and transfer of these nutrients would impart an advantage to the fungus. Even if this opportunistic necrotrophy were the only saprophytic function regularly performed by EM fungi in nature, on a landscape basis the sheer scale of root material being utilised would qualify them as significant recyclers of carbon.

\section{Conclusion}

In conclusion, it is true that data indicating saprophytic capabilities by EM fungi are still preliminary, and often conflicting. Hence, within the framework of the old paradigms, our results may be surprising. However, data from our studies and recent studies from other groups clearly demonstrate that EM fungi possess many of the genes shared with their most recent saprophytic common ancestors, and that they function in a flexible manner so that under times of high carbon demand or low host carbon availability they can turn on the genes that provide the potential for saprophytic behaviour. This discovery is interesting and can potentially shift paradigms in our understanding of mycorrhizal interactions. We agree with 
Dr Baldrian that more information is needed from DNA and RT-PCR studies of EM behaviour in natural soils, and this is exactly the direction we are taking. Our knowledge about global EM activities will also be enhanced through studies of specific enzymes involved in the degradation of woody substrates. As this topic moves forward, studies of the three components of EMs (extraradical mycelium, mantle and Hartig net) will be necessary to provide real insight into the ecological functions of these activities.

Acknowledgments Pierre-Emmanuel Courty gratefully acknowledges the Swiss National Science Foundation. Ken Cullings gratefully acknowledges the National Sciences Foundation, and the US Department of Agriculture.

\section{References}

Agerer R (2001) Exploration types of ectomycorrhizae: a proposal to classify ectomycorrhizal mycelial systems according to their patterns of differentiation and putative ecological importance. Mycorrhiza 11:107-114

Baier R, Ingenhaag J, Blaschke H, Göttlein A, Agerer R (2006) Vertical distribution of an ectomycorrhizal community in upper soil horizons of a young Norway spruce (Picea abies [L.] Karst.) stand of the Bavarian Limestone Alps. Mycorrhiza 16:197-206

Bidartondo MI, Burghardt B, Gebauer G, Bruns TD, Read DJ (2004) Changing partners in the dark: isotopic and molecular evidence of ectomycorrhizal liaisons between forest orchids and trees. Proc R Soc Lond B 271:1799-1806

Boland GJ, Melzer MS, Hopkin A, Higgins V, Nassuth A (2004) Climate change and plant diseases in Ontario. Can J Plant Pathol 26:335-350

Buée M, Courty PE, Mignot D, Garbaye J (2007) Soil niche effect on species diversity and catabolic activities in an ectomycorrhizal fungal community. Soil Biol Biochem 39:1947-1955

Courty PE, Pritsch K, Schloter M, Hartmann A, Garbaye J (2005) Activity profiling of ectomycorrhiza communities in two forest soils using multiple enzymatic tests. New Phytol 167:309-319

Courty PE, Pouysegur R, Buée M, Garbaye J (2006) Laccase and phosphatase activities of the dominant ectomycorrhizal types in a lowland oak forest. Soil Biol Biochem 38:1219-1222

Courty PE, Bréda N, Garbaye J (2007) Relation between oak tree phenology and the secretion of organic matter degrading enzymes by Lactarius quietus ectomycorrhizas before and during bud break. Soil Biol Biochem 39:1655-1663

Courty PE, Poletto M, Duchaussoy F, Buée M, Garbaye J, Martin F (2008a) Gene transcription in Lactarius quietus-Quercus petraea ectomycorrhizas from a forest soil. Appl Environ Microbiol 74:6598-6605

Courty PE, Franc A, Pierrat JC, Garbaye J (2008b) Temporal changes of the ectomycorrhizal community in two soil horizons of a temperate oak forest. Appl Environ Microbiol 74:5792-5801

Courty PE, Hoegger P, Kilaru S, Kohler A, Buée M, Garbaye J, Martin F, Kües U (2009) Phylogenetic analysis, genomic organization and expression analysis of multicopper oxidases in the ectomycorrhizal basidiomycete Laccaria bicolor. New Phytol 182:736-750

Cullings KW, New MH, Makhija S, Parker VT (2003) Effects of litter addition on the ectomycorrhizal associates of a lodgepole pine (Pinus contorta) stand in Yellowstone National Park. Appl Environ Microbiol 69:3772-3776

Cullings K, Ishkhanova G, Henson J (2008) Defoliation effects on enzyme activities of the ectomycorrhizal fungus Suillus granulatus in a Pinus contorta (lodgepole pine) stand in Yellowstone National Park. Oecologia 158:77-83

Dickie IA, Xu B, Koide RT (2002) Vertical niche differentiation of ectomycorrhizal hyphae in soil as shown by T-RFLP analysis. New Phytol 156:527-535

DiMarino E, Scattolin L, Bodensteinger P, Agerer R (2008) Sistotrema is a genus with ectomycorrhizal species - confirmation of what sequence studies have already suggested. Mycol Res 7:169-176

Gerini MF, Roccatano D, Baciocchi E, Di Nola A (2003) Molecular dynamics simulations of lignin peroxidase in solution. Biophys $\mathbf{J}$ 84:3883-3893

Goodman DM, Trofymow JA (1998) Distribution of ectomycorrhizas in micro-habitats in mature and old-growth stands of Douglas-fir on southeastern Vancouver Island. Soil Biol Biochem 30:21272138

Gramss G, Kirsche B, Voigt BK, Th Günther, Fritsche W (1999) Conversion rate of 5 polycyclic aromatic hydrocarbons in liquid cultures of fifty-eight fungi and concomitant production of oxidative enzymes. Mycol Res 103:1009-1018

Hibbett DS, Gilbert LB, Donoghue MJ (2000) Evolutionary instability of ectomycorrhizal symbioses in basidiomycetes. Nature 407:506-508

Hiner ANP, Ruiz JH, Lopez JNR, Canovas FG, Brisset NC, Smith AT, Arnao MB, Acosta M (2002) Reactions of class II peroxidases lignin peroxidase and Arthromyces ramusos peroxidase, with hyrdogen peroxide. J Biol Chem 277:26879-26885

Kellner H, Luis P, Buscot F (2007) Diversityof laccase-like multicopperoxidase genes in Morchellaceae: identification of genes potentially involved in extracellular activities related to plant litter decay. FEMS Microbiol Ecol 61:153-163

Koide RT, Sharda JN, Herr JR, Malcolm GM (2008) Ectomycorrhizal fungi and the biotrophy-saprotrophy continuum. New Phytol 178:230-233

Kusuda M, Ueda M, Konishi Y, Araki Y, Yamanaka K, Nakazawa M, Miyatake K, Terashita T (2006) Detection of $\beta$-glucosidase as saprotrophic ability from an ectomycorrhizal mushroom, Tricholoma matsutake. Mycoscience 47:184-189

Leonowicz A, Cho N-K, Luterek J, Wilkolazaka A, WojtasWasilewska M, Matuszewska A, Hofrichter M, Wesenberg D, Rogalski J (2001) Fungal laccase: properties and activity on lignin. J Basic Microbiol 41:185-227

Lindahl BD, Boberg J (2008) Distribution and function of litter basidiomycetes in coniferous forests. In: Boddy L, Frankland JC, Van West P, British Mycological Society (eds) Ecology of saprotrophic basidiomycetes. Elsevier, London, pp 183-196

Luis P, Walther G, Kellner H, Martin F, Buscot F (2004) Diversity of laccase genes from basidiomycetes in a forest soil. Soil Biol Biochem 34:1025-1036

Luis P, Kellner H, Martin F, Buscot F (2005) A molecular method to evaluate basidiomycete laccase gene expression in forest soils. Geoderma 128:18-27

Neville J, Tessier JL, Morrison I, Scarrat J, Canning B, Klironomos JN (2002) Soil depth distribution of ecto- and arbuscular mycorrhizal fungi associated with Populus tremuloides within a 3-year-old boreal forest clear-cut. Appl Soil Ecol 19:209-216

Nilsson RH, Larsson KH, Larsson E, Köljalg U (2006) Fruiting bodyguided molecular identification of root-tip mantle mycelia provides strong indications of ectomycorrhizal associations of two species of Sistotrema (Basidiomycota). Mycol Res 110:1426-1432

Rosling A, Landeweert R, Lindahl BD, Larsson K-H, Kuyper TW, Taylor AFS, Finlay RD (2003) Vertical distribution of ectomycorrhizal fungal taxa in a podzol soil profile. New Phytol 159:775-783

Tedersoo L, Kõljalg U, Hallenberg N, Larsson KH (2003) Fine scale distribution of ectomycorrhizal fungi and roots across substrate layers including coarse woody debris in a mixed forest. New Phytol 159:153-165 